\title{
MOLECULAR IDENTIFICATION OF Diplodia seriata De Not. CAUSING DIEBACK EFFECT ON GRAPEVINES AND EVALUATION OF in vitro EFFICACY OF FIVE DIFFERENT SYNTHETIC FUNGICIDES AGAINST THIS DISEASE
}

\author{
Nurdan GÜNGÖR SAVAŞ* ${ }^{*}$, Murat YILDIZ \\ Manisa Viticulture Research Institute, Plant Protection Department, 45125 Yunusemre, Manisa, TURKEY \\ Cite this article as: \\ Güngör Savaş N. \& Yıldız M. 2021. Molecular identification of Diplodia seriata De Not. causing dieback effect on grapevines and evaluation of in \\ vitro efficacy of five different synthetic fungicides against this disease. Trakya Univ J Nat Sci, 22(1): 93-100, DOI: 10.23902/trkjnat.863506
}

Edited by:

Mehmet Bora Kaydan

*Corresponding Author:

Nurdan Güngör Savaş

nurdangngrsvs10@gmail.com

ORCID iDs of the authors:

NGS. orcid.org/0000-0002-3450-4747

MY. orcid.org/0000-0002-0758-0429

Key words:

Botryosphaeriaceae

Dieback

Diplodia seriata

Vitis vinifera $L$.

\begin{abstract}
The aim of this study was to realize the molecular identification of Diplodia seriata De Not., a member of the Botryosphaericea family, isolated from 2-10 years old vines in vineyards showing symptoms of dieback disease. The susceptibility of the pathogen against the fungicides with the fosetyl-Al+triadimenol, azoxystorbin+difecanozole, fludioxanil+cyprodinil, metrafenone, fluopyram+tebuconazole combinations were evaluated. The isolates obtained from the root and crown parts of the vine samples were identified as $D$. seriata according to the morphological and molecular methods. In molecular identification, the ITS (Internal Transcribed Spacer) and TUB2 ( $\beta$-tubulin) gene regions of the isolates were amplified by Real-Time PCR and the nucleotide sequences were obtained in these gene regions. After using the MEGA 7 software, ITS and TUB2 sequences were aligned and a combined phylogenetic tree was made. It has been molecularly confirmed that the $D$. seriata isolate has a $100 \%$ similarity index with Diplodia species according to the phylogenetic analyses. The mean effective concentration $\left(\mathrm{EC}_{50}\right)$ values of fungicides used with different concentrations $(0,1,3,10,30,50,100 \mu \mathrm{L} \mathrm{mL}-1)$ were determined by Probit analysis. Cyprodinil + fludioxonil showed the highest efficacy (100\%) at a concentration of $1 \mu \mathrm{L} \mathrm{mL}^{-1}$. According to $\mathrm{EC}_{50}$ values, cyprodinil + fludioxonil $\left(0.001 \mu \mathrm{L} \mathrm{mL}^{-1}\right)$ was recorded as the most effective fungicide followed by fluopyram + tebuconazole $\left(0.520 \mu \mathrm{L} \mathrm{mL}^{-1}\right)$ and, azoxystrobin + difenoconazole $\left(2.958 \mu \mathrm{L} \mathrm{mL}^{-1}\right)$, respectively.
\end{abstract}

Özet: Bu çalışmanın amacı, geriye doğru ölüm hastalığı belirtileri gösteren bağlardaki 2-10 yaşındaki asmalardan izole edilen Botryosphaericea ailesinin bir üyesi olan Diplodia seriata De Not.'nın, moleküler tanılamasını gerçekleştirmektir. Patojenin duyarlılığı, fosetilAl+triadimenol, azoxystorbin+difecanozole, fludioxanil+cyprodinil, metrafenon, fluopyram+tebuconazole dâhil olmak üzere çeşitli fungisitlere karşı değerlendirilmiştir. Üreticiler tarafından getirilen asma örneklerinin kök ve kök boğazı kısımlarından elde edilen izolatlar, morfolojik ve moleküler yöntemlere göre $D$. seriata olarak tanımlanmıştır. Moleküler tanımlamada izolatların ITS (Internal Transcribed Spacer) ve TUB2 ( $\beta$-tubulin) gen bölgeleri Real-Time PCR ile çoğaltılmış ve bu gen bölgelerinden nükleotid dizileri elde edilmiştir. Daha sonra MEGA 7 yazılımı kullanılarak ITS ve TUB2 dizileri hizalanmış ve kombine bir filogenetik ağaç çizilmiştir. Diplodia seriata izolatının filogenetik analizlere göre Diplodia türleri ile \% 100 benzerlik indeksine sahip olduğu moleküler olarak doğrulanmıştır. Farklı konsantrasyonlarda $\left(0,1,3,10,30,50,100 \mu \mathrm{L} \mathrm{mL}^{-1}\right)$ kullanılan fungisitlerin ortalama etkili konsantrasyon $\left(\mathrm{EC}_{50}\right)$ değerleri Probit analiziyle belirlenmiştir. Cyprodinil+fludioxonil $1 \mu \mathrm{L}^{-1}$ konsantrasyonunda en yüksek etkinliği (\%100) göstermiştir. $\mathrm{EC}_{50}$ değerlerine göre cyprodinil+fludioxonil $\left(0.001 \mu \mathrm{L} \mathrm{mL}^{-1}\right)$ en etkili fungisit olarak kaydedilmiş, ardından fluopyram+tebuconazole $\left(0.520 \mu \mathrm{L}^{-1}\right)$ ve azoxystrobin+difenokonazol $\left(2.958 \mu \mathrm{L} \mathrm{mL}^{-1}\right)$ izlemiştir.

\section{Introduction}

Turkey is one of the countries including the most geographically favorable areas for viticulture. According to FAO 2019 statistics, Turkey has the $6^{\text {th }}$ largest land area devoted to vineyards with 470,000 hectares and is the $5^{\text {th }}$ largest grape producer in the world with 4.1 million tons per year (FAO 2019). In the country, the Aegean region ranks first in terms of both area $(1,392,082$ da) and production $(1,952,356$ tons per year) and the Manisa 
province ranks first in Aegean region with 809,123 da and $1,372,571$ tons per year (Anonymous 2019). More than $30 \%$ of the country's production is provided by this region. Manisa province supplies $90 \%$ of Turkey's dried grape production and is the leader in Sultani seedless grape production used for export (Anonymous 2019).

Botryosphaeria dieback, caused by members of the fungi family Botryosphaeriaceae, is an important disease in vines seen all over the world and in Turkey. Members of Botryosphaeriaceae in the Dothideomycetes class are found largely as endophytes, parasites, and saprophytes in both annual and perennial plants under different ecological conditions in many regions of the world (Slippers \& Wingfield 2007). The importance of these disease agents in vines was understood after it was first reported as a pathogen in the 2000s (Phillips 2002). The Eutypa dieback disease caused by Eutypa lata (Pers.) Tul. $\&$ C. Tul. has been thought to be responsible for cancers and deaths seen on vines in Australia for many years (Highet \& Wicks 1998, Pascoe \& Cottral 2000, CastilloPando et al. 2001, Siebert 2001). In Turkey, dieback, symptoms on vine leaves, and the development of brown color in wood tissue, which the shape of a "V", have been associated with Esca or Eutypa dieback disease as in Australia.

Identification of Botryosphaeria Ces. \& De. Not. diseases is problematic because symptoms occurring on vines in the field are very similar to other diseases such as Phomopsis dead arm disease caused by Phomopsis viticola (Sacc.) and Eutypa dieback caused by Eutypa lata (Castillo-Pando et al. 2001). Species of Botryosphaeria Ces. \& De. Not., Diplodia Fr., Lasiodiplodia Ellis \& Everh., Neofusicoccum Slippers \& A.J.L. Phillips in the family Botryosphaeriaceae have been isolated and described for the first time from vines showing dieback symptoms (Akgül et al. 2014). Diplodia seriata De Not. and Neofusicoccum luteum (Pennycook \& Samuels 1985) Crous, Slippers \& A.J.L. Phillips 2006 were often isolated from stems, branches and shoots that show symptoms during surveys conducted in vineyards in the sub-tropical region of eastern Australia (Savocchia et al. 2007).

Members of the genera Diplodia and Botryosphaeria have often been isolated from the root and crown parts of vine samples delivered to Manisa viticulture research institute plant health laboratory by producers in Aegean region. It has been reported that varieties of Vitis vinifera L. are generally more susceptible to disease (Larignon et al. 2001). Diplodia and Botryosphaeria species shorten the life of the vineyards, allow late awakening of the vines, lead to the formation of yellow dots on the leaves followed by necrotic spots with zebra pattern, killing of the shoots and the stem and eventually drying the vine backward, which are defined as important signs of the disease (Gramaje et al. 2018, Kühn et al. 2017). In addition to the Botryosphaeria species, fungi from the fungal families Botryosphaeria species, as well as fungi from Phaeoacremonium W. Gams, Crous, M. J. Wingf. \& Mugnai, Phaeomoniella Crous \& W. Gams, and Phomopsis Sacc. \& Roum were generally isolated the necrotic wood tissues showing symptoms of the disease. Botryosphaeria colonies are similar to Alternaria Nees colonies and are not noticed during the diagnostic phase based on colony development (Pitt et al. 2010, Úrbez-Torres 2011). The asexual spores of Diplodia spp. with spores of anamorphic of Botryosphaeria species are very similar, and a classification based only on the sexual situation is not suitable, especially since it is known that some species have only the asexual structures, and in some species, sexual development is extremely rare. Given these conditions, it has been determined that there are too many features in Botryosphaeriaceae that make it difficult to classify species (Slippers et al. 2013). For this reason, molecular diagnostics and even phylogenetic analysis are recommended. Ozben (2011) pointed to the presence of Botryosphaeria obtusa (Schwein.) Shoemaker and $B$. rhodina (Pat.) Griffon \& Maubl. in the vineyard areas of Ankara, but the presence of these species has not been approved molecularly and phylogenetically. In a study conducted in the Aegean region, Akgül et al. (2015) morphologically and molecularly identified the presence of $B$. dothidea and D. seriata in Sultani seedless vineyards, but phylogenetic analyses were not performed. Between 2015 and 2018, 22 Botryosphaeriaceae cultures were isolated from the vineyard areas in the Mediterranean and Southern Anatolia regions and they were phylogenetically separated (Akgül et al. 2020). It is very difficult to combat wood trunk diseases contained in wood tissue, and the applications for accurate diagnostics and combating are extremely important. Therefore, the present study was performed in order to evaluate the molecular characterization of Diplodia seriata isolated from the vineyards in Aegean Region and its sensitivity against five different fungicides.

\section{Materials and Methods}

\section{Isolation of the Disease Pathogen}

Sultani seedless vines ( $\mathrm{N}=23$ samples) showing dieback disease symptoms were obtained from growers in 2019 and 2020 from the vineyard areas in Manisa and Denizli province in Aegean Region. In addition to the symptoms the samples (including root regions) were those which dried in the vineyards. The information about the rootstock of the vines and the area where the vineyards were located were noted for those where $D$. seriate could have been isolated (Table 1). Preliminary examinations of the root, crown, and trunks revealed thick-fine lines in the wood tissue or brown necrosis spread over a wider area in the form of "V". 23 symptomatic samples from roots and cordons were cut, surface disinfection was performed by dipping into $1 \%(\mathrm{v} / \mathrm{v})$ sodium hypochlorite for $2 \mathrm{~min}$, and small pieces from the edge of necrotic and healthy tissues were removed and plated on potato dextrose agar (PDA) (Darmstadt, Germany). Petri dishes containing PDA were incubated for $4-5$ days in the dark at $25^{\circ} \mathrm{C}$, and micelle structures taken from fungal colonies that developed around tissues were purified by transferring them to new Petri dishes containing PDA according to colony properties and morphological structures (Phillips et al. 2007). 
Table 1. Provincial, county-village, and rootstock information of Sultani seedless vine samples showing signs of dieback.

\begin{tabular}{cccccc}
\hline \hline Sample No & Isolate code & Province & County-village & Vine rootstock & Age of the vines in years \\
\hline \hline $\mathbf{1}$ & *MBAE234N & Manisa & Yunusemre-Horozköy & 5BB & 9 \\
$\mathbf{2}$ & MBAE244N & Manisa & Yunusemre-Muradiye & 1103Paulsen & 6 \\
$\mathbf{3}$ & MBAE275N & Manisa & Yunusemre-Evrenos & 110R & 3 \\
$\mathbf{4}$ & MBAE288N & Manisa & Yunusemre-Horozköy & 1103Paulsen & 5 \\
$\mathbf{5}$ & MBAE312N & Manisa & Yunusemre-Horozköy & 1103Paulsen & 4 \\
$\mathbf{6}$ & MBAE313N & Manisa & Akhisar-Sazoba & SO4 & 10 \\
$\mathbf{7}$ & MBAE336N & Manisa & Şehzadeler-Hacihaliller & 1103Paulsen & 4 \\
$\mathbf{8}$ & MBAE344N & Manisa & Gölmarmara-Kayaaltı & 1103Paulsen & 2 \\
$\mathbf{9}$ & MBAE358N & Manisa & Saruhanl1-Nuriye & 5BB & 7 \\
$\mathbf{1 0}$ & MBAE359MN & Denizli & Çal & 5BB & 3 \\
$\mathbf{1 1}$ & MBAE368MN & Denizli & Buldan-Yenicekent & 110R & 6 \\
\hline \hline
\end{tabular}

* Naming MBAE is an abbreviation for the research institute where isolates were isolated. Number is the sequence number in the cultural collection. N/NM next to the number is the name abbreviation of the person/persons isolating it.

The mycelial discs from pure cultures were then transferred to Eppendorf tubes containing sterile 30\% glycerol and stored at $-80^{\circ} \mathrm{C}$.

\section{Molecular diagnosis of Diplodia seriata and phylogenetic analysis}

Molecular diagnosis and phylogenetic analyses were carried out by selecting two isolates (MBAE359NM, MBAE368NM) from $11 D$. seriata isolates obtained purely and very similar to each other from morphologicalmicroscopic aspects. A total of $50 \mathrm{mg}$ fresh mycelial mass was taken from the colonies of these two isolates, and DNA extraction was carried out. The micelle were put into sterile $1.5 \mathrm{~mL}$ Eppendorf tubes and crushed with Evolution Homogenizer (Precellys ${ }^{\circledR}$ Evolution, Paris, France), and $550 \mu \mathrm{L}$ DNA extraction buffer $(200 \mathrm{mM}$ Tris- $\mathrm{HCl})$ was added. DNA was obtained according to the proposed method of Cenis (1992) using $250 \mathrm{mM} \mathrm{NaCl}, 25 \mathrm{mM}$ EDTA and 2\% Sodium Dodecyl Sulphate. The concentration and purity of the isolated DNA were determined with a Multiscan GO $\mu$-drop plate (Thermo Scientific, Vantaa, Finland). In PCR studies, the internal transcribed spacers (ITS) rDNA region was amplified with the ITS4 (5'-TCCTCCGCTTATTGATATGC-3') and ITS5 (5'-GGAAGTAAAAGTCGTAACAAGG-3') primer pair (White et al. 1990), and the $\beta$-tubulin (TUB2) gene region was amplified with $\beta \mathrm{t}-2 \mathrm{a} \quad\left(5^{\prime}-\right.$ GGTAACCAAATCGGTGCTGCTTTC- $\left.3^{\prime}\right)$ and $\beta \mathrm{t}-2 \mathrm{~b}\left(5^{\prime}-\right.$ ACCCTCAGTGTAGTGACCCTTGGC-3') primer pair (Glass \& Donaldson 1995). In real-time PCR reactions, 0.3 $\mu \mathrm{L} 20 \mu \mathrm{M}$ forward primer, $0.3 \mu \mathrm{L} 20 \mu \mathrm{M}$ reverse primer, 2 $\mu \mathrm{L}$ DNA, and $10 \mu \mathrm{L} 2 \mathrm{x}$ FastStart Essential DNA Green Master Mix were added into sterile PCR tubes, and the final volume was completed with DNase/RNase pure water to 20 $\mu \mathrm{L}$. Real-time PCR (Roche Light Cycler ${ }^{\circledR}$ Nano) amplification conditions included the initial denaturation for $10 \mathrm{~min}$ at $95^{\circ} \mathrm{C}$, denaturation for $30 \mathrm{~s}$ at $95^{\circ} \mathrm{C}, 54^{\circ} \mathrm{C}$ for annealing temperature of ITS, $58^{\circ} \mathrm{C}$ for TUB2, and 35 cycles for $1 \mathrm{~min}$. at $72^{\circ} \mathrm{C}$. After PCR amplification, melting analysis eliminated non-specific amplifications such as primer dimers and determined whether the replicated area was the target region. Sequence data of the PCR products were obtained by a two-way genome sequencing service from a laboratory that provides Sanger sequence service (by TrioGene firm). Chromatogram files of sequence data were analyzed with ChromasPro 1.7.6 chromatogram analysis software, and consensus sequences were obtained by combining sequence data with forward and reverse sequences. BLASTn analyzes fungal species were performed using the consensus sequences obtained for each gene region in the National Center for Biotechnology Information (NCBI) GenBank database. According to these results, access numbers were obtained from the NCBI GenBank library of diagnosed isolates. For phylogenetic analyses, sequences belonging to an isolate were primarily aligned with Bioedit 7.2.5 sequence alignment software, then similarity ratios of nucleotide sequences were determined by the Clustal W software. The dendrogram of data of nucleotide sequences was created using the Mega 7 software and the Maximum likelihood model (Tamura et al. 2011) and confirmation of the obtained phylogenetic tree was made with 1000 repetitions (Bootstrap, p-distance, pairwise deletion). The access numbers of the isolates obtained in this study and the references from the GenBank database in the phylogenetic tree are listed in Table 2.

Evaluation of susceptibility of Diplodia seriata to fungicides in in-vitro conditions

To test the effect of fungicides on the development of mycelia in in vitro conditions, the fungicides given in Table 3 were used. The MBAE368MN isolate was used for this experimental step. The fungicidal activity of the fungicides was evaluated in the growth culture containing the same concentrations $(0,1.0,3.0,10.0,30.0,50.0$, 100.0 PDA containing $\mu \mathrm{g} / \mathrm{mL}$ ). Stock solutions of each fungicide were prepared and concentrations from stock solutions were mixed into a sterile PDA medium cooled to $50^{\circ} \mathrm{C}$ and poured into Petri dishes (Isolab, $90 \times 100 \mathrm{~mm}$ ). As a control, Petri dishes with a PDA medium free from fungicides were used. Six mm diameter mycelial discs cut from the edges of the fungal colony of the 5-day-old $D$. seriata isolate (MBAE368NM) were placed to the center 
Table 2. Isolates obtained from the GenBank database and references in the phylogenetic tree.

\begin{tabular}{|c|c|c|c|c|c|}
\hline \multirow{2}{*}{ Species } & \multirow{2}{*}{ Isolate } & \multirow{2}{*}{ Host } & \multirow{2}{*}{ Origin } & \multicolumn{2}{|c|}{ GenBank Accession Nos. } \\
\hline & & & & ITS & TUB2 \\
\hline Diplodia seriata & "MBAE359MN* & V. vinifera & Turkey & MT880771 & MT914171 \\
\hline Diplodia seriata & MBAE368MN* & V. vinifera & Turkey & MT880774 & MT914174 \\
\hline Diplodia seriata & CBS: 114791 & $V$. vinifera & South Africa & KX464107 & KX464833 \\
\hline Botryosphaeria obtusa & CBS 112555 & $V$. vinifera & Portugal & AY259094 & DQ458856 \\
\hline Diplodia seriata & CBS 113527 & V. vinifera & South Africa & KX464106 & KX464832 \\
\hline Diplodia mutila & CBS 136014 & Populus alba $\mathrm{L}$. & Portugal & KJ361837 & MG015815 \\
\hline Diplodia mutila & CBS 431.82 & V. vinifera & France & KU198424 & KU198426 \\
\hline $\begin{array}{l}\text { Lasiodiplodia theobromae (Pat.) } \\
\text { Griffon \& Maubl. }\end{array}$ & CBS 111530 & Proteaceae & Netherlands & FJ150695 & KU887531 \\
\hline Lasiodiplodia theobromae & CBS 164.96 & Fruit along coral reef coast & $\begin{array}{l}\text { Papua New } \\
\text { Guinea }\end{array}$ & NR_111174.1 & EU673110.1 \\
\hline $\begin{array}{l}\text { Neofusicoccum parvum (Pennycook \& } \\
\text { Samuels) Crous, Slippers \& A.J.L. } \\
\text { Phillips }\end{array}$ & CBS 123652 & $\begin{array}{l}\text { Syzygium cordatum } \\
\text { (Hochst.) }\end{array}$ & South Africa & KX464184 & KX464996 \\
\hline Neofusicoccum parvum & CBS 257.77 & Cocos nucifera $\mathrm{L}$. & India & KX464197 & KX465012 \\
\hline Neofusicoccum luteum & CBS 562.92 & $\begin{array}{l}\text { Actinidia deliciosa (A.Chev.) } \\
\text { C.F.Liang \& A.R.Ferguson }\end{array}$ & New Zeland & KX464170 & KX464968 \\
\hline Neofusicoccum luteum & CBS 612.83 & Persea Americana Mill & USA & KX464171 & KX464969 \\
\hline $\begin{array}{l}\text { Tiarosporella tritici } \\
\text { B. Sutton \& Marasas }\end{array}$ & CBS 118719 & Triticum sp. & South Africa & KF531830 & KF531810 \\
\hline
\end{tabular}

* Isolates registered in GenBank and their accession numbers.

Table 3. The active ingredient, formulation, and company information of the fungicides used in determining fungicidal activity in in vitro conditions.

\begin{tabular}{llcc}
\hline \hline Active ingredient $\%$ & Commercial Name & Firm & Formulation Type* \\
\hline \hline Cyprodinil+Fludioxonil, $\% 37.5+\% 25$ & Switch 62.5 & Syngenta & WG \\
Fluopyram+Tebuconazole, $200 \mathrm{~g} / \mathrm{L}+200 \mathrm{~g} / \mathrm{L}$ & Luna Experience & Bayer & SC \\
Azoxystrobin+Difenoconazole, $200 \mathrm{~g}+125 \mathrm{~g}$ & Quadris Maxx & Syngenta & SC \\
Folpet+Triadimenol, $700 \mathrm{~g} / \mathrm{kg}+20 \mathrm{~g} / \mathrm{kg}$ & Shavit F 72 & Adama & WDG \\
Metrafenone, $500 \mathrm{gr} / \mathrm{L}$ & Vivando & Basf & SC \\
\hline \hline
\end{tabular}

*WG, WDG: Water dispersible granule of formulation type, SC: Water soluble concentrate of formulation type.

of the growth culture containing fungicide concentrations. All inoculated application and control Petri dishes were incubated in darkness at $20^{\circ} \mathrm{C}$ for 7 days. During this period, the rates of blocking micelle by fungicides (\%) were examined by measuring the radial development of fungal micelles (Uysal \& Kurt 2019).

In the trials, randomized controlled trials were established so that each Petri dish represented one replication and each concentration has 3 replications. The experiment was repeated at 2 different times.

\section{Calculations and Statistical Evaluation}

In vitro trials were set up to have 3 replications for each application, according to the randomized controlled trial. For establishing antifungal efficacy in petri dishes containing fungicide concentrations, variation analysis was carried out with one-way ANOVA using SPSS Statistics (Version 17.0, SPSS Inc., Chicago, IL, USA) without converting the blocking rates of micelle development in petri dishes $(\mathrm{p} \leq 0.05)$. Effective concentrations of fungicides that inhibit the development of micelles at $50 \%$ level $\left(\mathrm{EC}_{50}\right)$ were determined by Probit analysis with the help of the SPSS statistics using the values obtained in different concentrations for each chemical.

\section{Results}

Isolation and morphological characteristics of the disease agent

Eleven Diplodia seriata isolates were obtained during the isolation from the root and crown regions of the samples taken from Sultani seedless vine varieties showing signs of dieback in the vineyards in Manisa and Denizli provinces. Wedge-shaped brown lines and necrotic tissues ranging from brown to black color were observed in the root areas of the isolated samples. On the upper part of the vine, yellow spots in the form of dots on the leaves, necrotic spots with zebra pattern, and backward drying on the shoots were found to be remarkable.

Colonies that develop in a PDA medium were initially colorless or light olive green-gray in color but darkened and blacken in time (Fig. 1A and B). The conidia were dark brown in colour and oval, broad at the apex and truncated or rounded at the base, and its wall was rough. Immature spores were without compartment and formed darker brown single-compartment spores as they matured. Forty conidia per isolate were measured by light microscopy (Olympus BX-51 connected with Olympus Camedia-4501X, Hamburg, Germany). The 
size of the conidia was measured as $27.4 \pm 0.31 \times 10.8 \pm$ $0.15 \mu \mathrm{m}$, with no significant differences between the isolates, and it was determined to be the same as the characteristics of D. seriata (teleomorph: Botryosphaeria obtusa) specified in morphological diagnostics made by Phillips et al. (2007).

\section{Molecular diagnosis and phylogenetic analyses}

By using primers specific to ITS (ITS-1 and ITS-4), TUB2 ( $\beta \mathrm{t}-2 \mathrm{a}$ and $\beta \mathrm{t}-2 \mathrm{~b})$ gene regions, PCR, and DNA sequencing of MBAE359MN and MBAE368MN isolates selected among the fungal isolates resulted in the $580 \mathrm{bp}$ and $434 \mathrm{bp}$ bands, respectively. By comparing the nucleotide sequences with sequences in the NCBI GenBank (BLASTn), the isolates were found to be $D$. seriata. As a result of Blast comparison with species registered in GenBank, they were found to have a 97-
$100 \%$ resemblance to MBAE359MN and MBAE368MN $D$. seriata isolates (for ITS and TUB gene regions, the access numbers are KX464107, KX464833, and KX464106, KX464832, respectively). The nucleotide sequences of D. seriata MBAE359MN and MBAE368MN isolates, which were morphologically and molecularly determined, were uploaded to the GenBank database and obtained the access number MT880771 and MT880773 were obtained for the ITS gene and MT914171 and MT914174 for the TUB2 gene. A combined dendrogram was obtained for the ITS and TUB 2 genes with MEGA 7 software using the maximum likelihood method (Fig. 2). According to the dendrogram, MBAE359MN and MBAE368MN isolates were in the same group as D. seriata CBS: 114791, CBS 112555, and CBS:113527 isolates. Tiarosporella tiritici CBS 118719 was determined as an external group (Fig. 2).

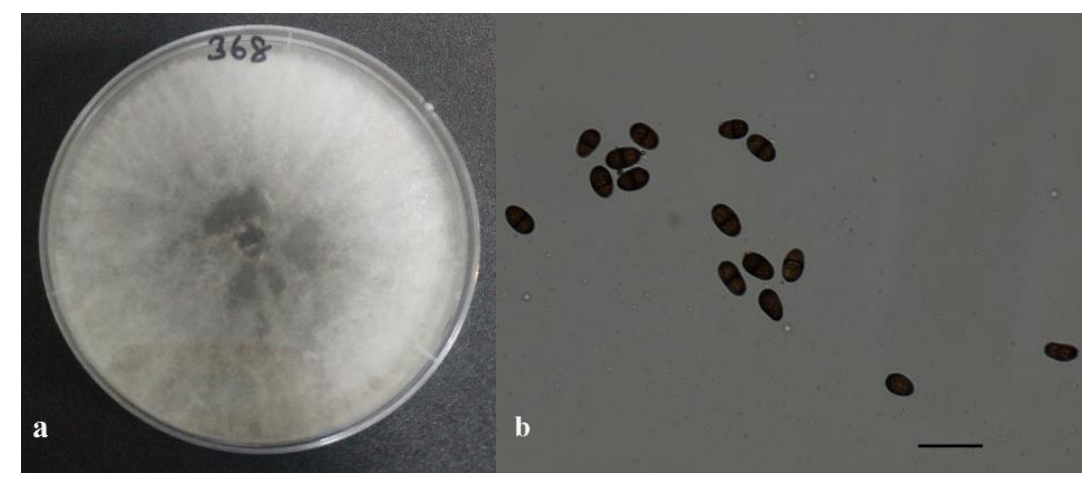

Fig. 1. Diplodia seriata; a. 7-day views of young colonies on PDA, b. Conidia, scale $10 \mu \mathrm{m}$.

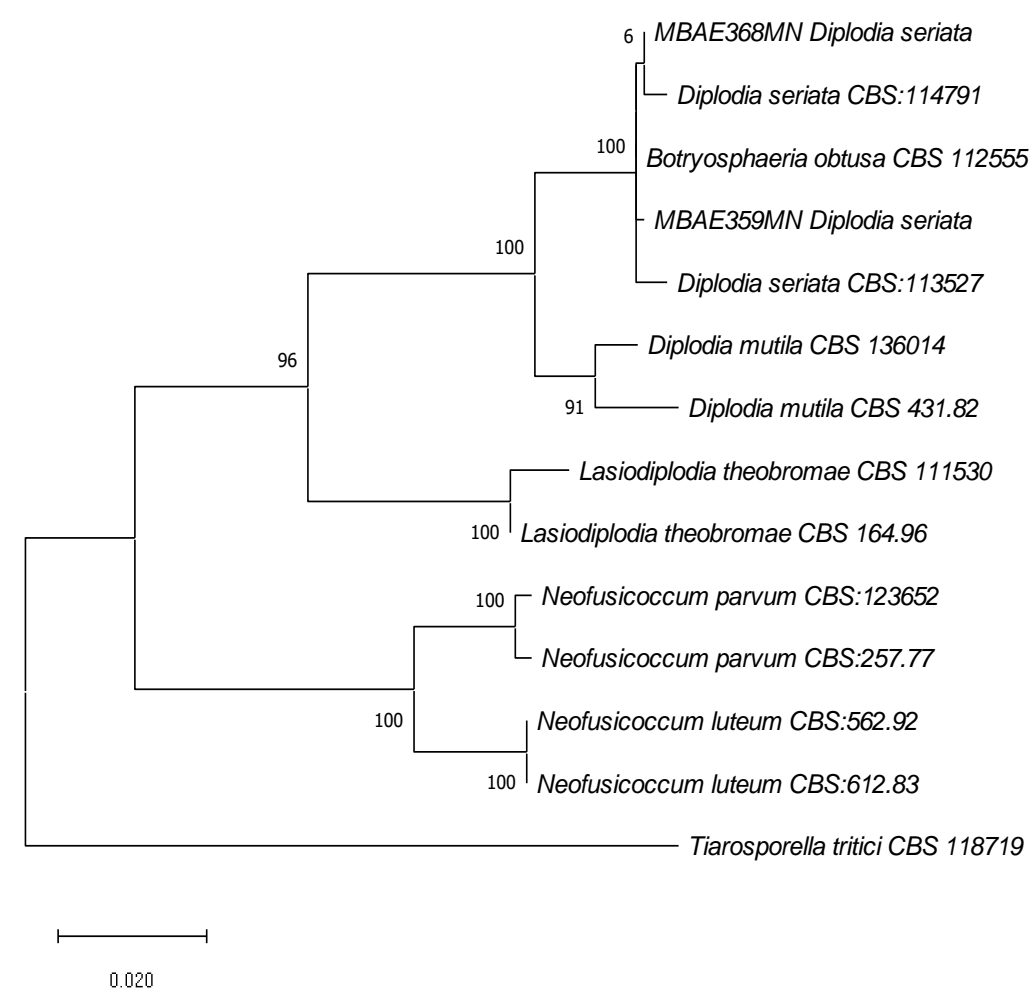

Fig. 2. Phylogenetic relationships of some Botryosphaeriaceae species according to the maximum similarity model obtained by the combination of ITS and TUB2 gene regions (Maximum Likelihood). The reliability of the phylogenetic tree was calculated with 1000 replications by the Bootstrap method. Bootstrap values below 50\% were not shown. Tiarosporella tritici (CBS 118719) is the outside group. The scale bar shows the number of nucleotide changes. 
Table 4. Antifungal effects of the tested fungicides on Diplodia seriata MBAEM368MN isolate as revealed by in vitro-micelle growth prevention.

\begin{tabular}{|c|c|c|c|c|}
\hline Active substance & $\begin{array}{l}\text { Replication } 1 \mathrm{EC}_{50} \\
\text { value ** }\left(\mu \mathrm{g} \mathrm{mL}^{-1}\right)\end{array}$ & $\begin{array}{l}\text { Replication } 2 \text { EC }_{50} \\
\text { value }\left(\mu \mathrm{g} \mathrm{mL}^{-1}\right)\end{array}$ & $\begin{array}{c}\text { Replication } 3 \text { EC } 50 \\
\text { value }\left(\mu \mathrm{g} \mathrm{mL}^{-1}\right)\end{array}$ & $\begin{array}{c}\text { Average } \\
\text { EC }_{50} \text { value }\left(\mu \mathrm{g} \mathrm{mL}^{-1}\right)^{*}\end{array}$ \\
\hline Cyprodinil+Fludioxonil, & 0.001 & 0.001 & 0.001 & $0.001 \pm 0.00 \mathrm{a}$ \\
\hline Fluopyram+Tebuconazole & 0.453 & 0.434 & 0.673 & $0.520 \pm 0.08 \mathrm{a}$ \\
\hline Azoxystrobin+Difenoconazole & 2.847 & 2.006 & 4.021 & $2.958 \pm 0.58 \mathrm{a}$ \\
\hline Folpet+Triadimenol & 4.962 & 5.721 & 7.546 & $6.076 \pm 0.76 \mathrm{ab}$ \\
\hline Metrafenone & 4.996 & 21.090 & 7.585 & $11.223 \pm 4.99 \mathrm{~b}$ \\
\hline
\end{tabular}

* Different letters next to the mean $\mathrm{EC}_{50}\left(\mu \mathrm{g} / \mathrm{mL}^{-1} \pm\right.$ S.E) in the row indicate that the difference between the applications is statistically significant according to the Duncan Multiple Comparison Test $(\mathrm{p}<0.05)$.

**Effective concentrations $\left(\mathrm{EC}_{50}\right)$ of fungicides that inhibit micelle growth by $50 \%$ were estimated by using the values obtained at different concentrations for each fungicide by Probit analysis with the help of SPSS statistical software (Version 17.0, SPSS Inc., Chicago, IL, USA).

Determination of susceptibility of the disease agent to fungicides in in-vitro conditions

The effective concentration $\left(\mathrm{EC}_{50}\right)$ values required for fungicides used in the study to prevent micelle development of disease factor $D$. seriata by $50 \%$ were determined by the SPSS statistical software Probit analysis. When the antifungal effects of fungicides with different active substances preventing micelle growth of D. seriata MBAEM $368 \mathrm{MN}$ isolate in in vitro conditions were examined, it was observed that the disease agent was quite sensitive to other fungicides except for metrafenone. Among the fungicides, cyprodinil+fludioxonil showed the highest efficacy $(100 \%)$ at a concentration of $1 \mu \mathrm{g} \mathrm{mL}^{-1}$. The highest activity was recorded as cyprodinil+fludioxonil with the lowest $\mathrm{EC}_{50}$ value as $0.001 \mu \mathrm{g} \mathrm{mL}^{-1}$, followed by fluopyram+tebuconazole with $0.520 \mu \mathrm{g} \mathrm{mL}^{-1}$, azoxystrobin+difenoconazole with 2.958 $\mu \mathrm{g} \mathrm{mL} \mathrm{m}^{-1}$, and folpet+triadimenol with $6.076 \mu \mathrm{g} \mathrm{mL}$ respectively. The lowest efficacy was obtained from metrafenone active substance with the highest $\mathrm{EC}_{50}$ value of $11.223 \mu \mathrm{g} \mathrm{mL}^{-1}$ (Table 4). Cyprodinil+fludioxonil, fluopyram+tebuconazole, azoxystrobin+difenoconazole fungicides were in the same statistical group with low $\mathrm{EC}_{50}$ values and were determined as the most effective fungicides against $D$. seriata MBAEM368MN isolate.

\section{Discussion}

Diplodia seriata was isolated from the root and crown parts of the Sultani seedless vine varieties between of 210 years old, grafted on different rootstocks in Denizli and Manisa in Aegean Region. In a study examining cross infections of Ilyonectria spp. and Botryosphaeriaceae family that cause dieback in young vines in Australia; $D$. seriata, D. mutila (Fries) Montagne, and Lasiodiplodia theobromae were isolated from $79.8 \%$ and $8 \%$ of Chardonny and Ramsey rootstocks, respectively. Diplodia seriata and D. mutila were detected from the roots of $10 \%$ and $5 \%$ of the plants showing the symptoms, respectively (Pitt et al. 2010). In a study conducted in 2015 in the Sultani seedless vineyard areas in Aegean Region, it was reported that at least one grapevine stem disease was seen in more than $80 \%$ of the vineyards who were at least 10 years old, and Botryosphaeriaceae species were the most isolated pathogens with $1.3 \%$
(Akgul et al. 2015). However, Billones-Baaijens et al. (2013) found that D. seriata and D. mutila were less virulent in green shoots compared to the three Neofusicoccum species. These Diplodia species were equally virulent when grafted into rooted strawberries, and these species may be tissue-specific pathogens also may be explain the reason for the endophytic behavior of these pathogens as their high availability from asymptomatic breeding materials and nurseries.

It is difficult to differentiate Diplodia species based on their conidial morphology because they are very similar to each other. The time of onset of conidia pigmentation in Diplodia species, and very small differences in color and compartments aid in distinction (Phillips et al. 2008, 2012). It is noted that the conidia in most Diplodia species remains hyaline for a long time and may never actually be brown. However, species within the group are characterized by brown, aseptate conidia (such as $D$. seriata and $D$. sapinea (Fries) Fuckel), pigmented conidia (Phillips et al. 2013). In our study, the isolates obtained based on morphological characters of fungal structures of diseased plants were described as $D$. seriata De Not (teleomorph "Botryosphaeria" obtusa) (Phillips et al. 2007, Chebil et al. 2017). By phylogenetic analysis, the two Diplodia species were clustered on two different branches in the same group. It has been molecularly confirmed that the Diplodia seriata isolate has a $100 \%$ similarity index with Diplodia species. In a study on species in the Botryosphaeriaceae family associated with dieback in Vine in China, Lasiodiplodia theobromae, Neofusicoccum parvum, Botryosphaeria dothidea and, D. seriata were determined as pathogens by their molecular characterization of the ITS, TUB, and EF1- $\alpha$ gene regions (Yan et al. 2013).

A number of studies have been carried out on members of the Botryosphaeriaceae family, which leads to dieback in vines (Luque et al. 2009, Urbez-Torres \& Gubler 2009). In a study that evaluated fungicides for the control of Botryosphaeria dieback disease in vines in New Zealand, 8 of the 16 tested fungicides were been found to be effective in preventing conidial germination and mycelial growth in against Neofusicoccum australe (Slippers, Crous \& Wingfield) Crous, Slippers \& Phillips, 
N. luteum, and D. mutila. Flusilazole, carbendazim, tebuconazole, prochlorase, procymidone, iprodione, fenarimol, thiophanate methyl, chlorothalonil, and mancozeb $1 \mu \mathrm{g} \mathrm{mL}^{-1}$ were found to be the most effective against these three Botryosphaeria species in in vitro with lower average $\mathrm{EC}_{50}$ values (Amponsha et al. 2012). The effectiveness of 20 different fungicides used against Botryosphaeria cancer in the vineyards in Australia was revealed by in vitro trials using $B$. dothidea, $N$. parvum, $L$. theobromae, and D. seriata. Fludioxonil, carbendazim, fluazinam, tebuconazole, flusilazole, penconazole, procymidone, iprodione, myclobutanil, and pyraclostrobin, with a value of $<1.0 \mathrm{mg} \mathrm{L}^{-1}$, were identified as the most effective fungicides (Pitt et al. 2012).

Diplodia seriata, isolated in the present study was determined as the dieback disease in vines in Manisa and Denizli provinces in Aegean region. It is thought that this agent can be found in the root and crown region and accelerates dieback according to the region in which it is located.

The effects of fungicides with different chemical structures against the disease agent isolated from the vineyard were tested for the first time in in vitro conditions. Cyprodinil + fludioxonil and fluopyram + tebuconazole were found to be the most effective fungicides against $D$. seriata MBAEM $368 \mathrm{MN}$ isolate with low $\mathrm{EC}_{50}$ values. For complete control of dieback disease, an integrated control system that encompasses the entire life cycle of grapevines is necessary. In future

\section{References}

1. Akgül, D.S., Savas, N.G. \& Eskalen, A. 2014. First report of wood canker caused by Botryosphaeria dothidea, Diplodia seriata, Neofusicoccum parvum, and Lasiodiplodia theobromae on grapevine in Turkey. Plant Diseases, 98: 568.

2. Akgül, D.S., Savas, N.G., Teker, T., Keykubat, B., Mayorquin, J.S. \& Eskalen, A. 2015. Fungal trunk pathogens of Sultana seedless vineyards in Aegean region of Turkey. Phytopathologia Mediterranea, 54(2): 380-393.

3. Akgül, D.S., Ozarslandan, M. \& Erkılıç, A. 2020. Phylogenetic discrimination and pathogenicity of fungi causing Botryosphaeria dieback disease on grapevine in Southern Turkey. Plant Protection Bulletin, 60(2): 63-72.

4. Amponsah N.T., Jones E., Ridgway H.J. \& Jaspers M.J. 2012.Evaluation of fungicides for the management of Botryosphaeria dieback diseases of grapevines. Pest Management Science, 68: 676-683.

5. Anonymous, 2019. Agricultural Products Markets GRAPE. https://arastirma.tarimorman.gov.tr/tepge/Belgeler/PDF\% 20Tar\%C4\%B1m\%20\%C3\%9Cr\%C3\%BCnleri\%20Piyas alar\%C4\%B1/2019Ocak\%20Tar\%C4\%B1m\%20\%C3\%9 Cr\%C3\%BCnleri\%20Raporu/2019-

Ocak\%20\%C3\%9Cz\%C3\%BCm.pdf. (Data Accessed: May 2020).

6. Billones-Baaijens, R., Ridgway, H.J., Jones, E.E. \& Jaspers, M.V. 2013. Prevalence and distribution of Botryosphaeriaceae studies, integration of well-planned cultural methods and chemical control practices that will provide optimum protection in field conditions can be realized. It may also be recommended to add the Switch 62.5 and Luna Experience fungicides with good results according to $\mathrm{EC}_{50}$ values in chemical control applications.

\section{Acknowledgement}

This study was carried out in the laboratory of The Plant Health Clinic of the Directorate of Manisa Viticulture Research Institute. A part of this study was presented as a short summary at II. International Agricultural, Biological \& Life Science Conference (EAgbiol), held in Edirne, Turkey, from September 1 to 3, 2020.

Ethics Committee Approval: Since the article does not contain any studies with human or animal subject, its approval to the ethics committee was not required.

Author Contributions: Concept: N.G.S., M.Y., Desing: N.G.S., M.Y., Execution: N.G.S., M.Y., Material supplying: N.G.S., M.Y., Data acquisition: N.G.S., M.Y., Data analysis/interpretation: N.G.S., M.Y., Writing: N.G.S., M.Y.

Conflict of Interest: The authors have no conflicts of interest to declare.

Funding: The authors declared that this study has received no financial support.

species in New Zealand grapevine nurseries. European Journal of Plant Pathology, 135: 175-85.

7. Castillo-Pando, M., Somers, A., Green, C.D., Priest, M. \& Sriskanthades, M. 2001. Fungi associated with dieback of Semillon grapevines in the Hunter Valley of New South Wales. Australasian Plant Pathology, 30: 59-63.

8. Chebil, S., Fersi, R., Bouzid, M., Quaglino, F., Chenenaoui, S., Melki, I., Durante, G., Zacchi, E., Bahri, B.A., Bianco, P.A. \& Rhouma, A. 2017. Fungi from the Diaporthaceae and Botryosphaeriaceae families associated with grapevine decline in Tunisia. Ciencia e Investigación Agraria, 44(2): 127-138.

9. FAO. 2019. Food and Agricultural Organization, Statistics Division. http://www.fao.org. (Date Accessed: April 2020).

10. Glass, N. \& Donalds, G.C. 1995. Development of primer sets designed for use with the PCR to amplify conserved genes from filamentous ascomycetes. Applied and Environmental Microbiology, 61(4): 1323-30.

11. Gramaje D., Úrbez-Torres, J.R. \& Sosnowski, M.R. 2018. Managing Grapevine Trunk Diseases with respect to etiology and epidemiology: Current Strategies and Future Prospects. Plant Diseases, 102(1): 12-39.

12. Highet, A. \& Wicks, T. 1998. The incidence of Eutypa dieback in South Australia vineyards. Annual Technical Issue. The Australian Grape Grower and Wine-maker, 414: 135-136. 
13. Kühn A., Zappata, A., Gold, R.E., Zito, R. \& Kortekamp, A. 2017. Susceptibility of grape pruning wounds to grapevine trunk diseases and effectiveness of a new BASF wound protectant. Phytopathologia Mediterranea, 56(3): 536 (abstract).

14. Larignon, P., Fulchic, R., Cere, L. \& Dubos, B. 2001. Observation on black dead arm in French vineyards. Phytopathologia Mediterranea, 40: 336-342.

15. Luque J., Martos, S., Aroca, A., Raposoand, R. \& GarciaFihueres, F. 2009. Symptoms and fungi associated with declining mature grapevine plants in northeast Spain. Journal of Plant Pathology, 91: 381-390.

16. Ozben, S. 2011. Determination of Fungal Diseases and Their Prevalence in Vineyard in Ankara Provinces. Ankara University Graduate School of Natural and Applied Sciences Department of Plant Protection, Master Thesis, Ankara, 134pp.

17. Pascoe, I. \& Cottral, E. 2000. Developments in grapevine trunk diseases research. Phytopathologia Mediterranea, 39: 68-75.

18. Phillips, A.J.L. 2002. Botryosphaeria species associated with diseases of grapevines in Portugal. Phytopathologia Mediterranea, 41: 3-18.

19. Phillips, A.J.L., Crous, P.W \& Alves, A. 2007. Diplodia seriata, the anamorph of "Botryosphaeria" obtusa. Fungal Diversity, 25: 141-155.

20. Phillips, A.J.L., Alves, A., Pennycook, S.R., Johnston, P.R. \& Ramaley, A. 2008. Resolving the phylogenetic and taxonomic status of dark-spored teleomorph genera in the Botryosphaeriaceae. Molecular Phylogeny and Evolution of Fungi, 21: 2955.

21. Phillips, A.J.L., Lopes, J., Abdollahzadeh, J., Bobev, S. \& Alves, A. 2012. Resolving the Diplodia complex on apple and other Rosaceae hosts. Molecular Phylogeny and Evolution of Fungi, 29: 29-38.

22. Phillips, A.J.L., Alves, A., Abdollahzadeh, J., Slippers, B., Wingfield, M.J., Groenewald, J.Z. \& Crous, P.W. 2013. The Botryosphaeriaceae: genera and species known from culture. Studies in Mycology, 76: 51-167.

23. Pitt, W.M., Sosnowski, M.R., Huang, R., Qiu, Y., Steel, C.C. \& Savocchia, S. 2012. Evaluation of fungicides for the management of Botryosphaeria canker of grapevines. Plant Diseases, 96: 1303-1308.

24. Pitt, W.M., Huang, R. \& Steel, C.C. 2010. Identification, distribution and current taxonomy of Botryosphaeriaceae species associated with grapevine decline in New South Wales and South Australia. Australian Journal of Grape and Wine Research, 16: 258-271.

25. Savocchia S., Steel C.C., Stodart, B.J. \& Somers, A., 2007. Pathogenicity of Botryosphaeria species from declining grapevines in subtropical regions of Eastern Australia. Vitis, 46(1): 27-32.

26. Siebert, J.B. 2001. Eutypa: the economic toll on vineyards. Wines and Vines, 4: 50-56.

27. Slippers, B. \& Wingfield, M.J. 2007. Botryosphaeriaceae as endophytes and latent pathogens of woody plantsdiversity, ecology and impact. Fungal Biology Reviews, 21: 90-106.

28. Slippers, B., Boissin, E., Phillips, A.J.L., Groenewald, J.Z. \& Wingfield, M.J. 2013. Phylogenetic lineages in the Botryosphaeriales: A systematic and evolutionary framework. Studies in Mycology, 76: 31-49.

29. Tamura, K., Peterson, D., Peterson, N., Stecher, G., Nei, M. \& Kumar, S. 2011. MEGA5: molecular evolutionary genetics analysis using maximum likelihood, evolutionary distance, and maximum parsimony methods. Molecular Biology and Evolution, 28: 2731-2739.

30. Úrbez-Torres, J.R. \& Gubler, W.D. 2009. Pathogenicity of Botryosphaeriaceae species isolated from grapevine cankers in California. Plant Disease, 93: 584-592.

31. Úrbez-Torres, J.R. 2011. The status of Botryosphaeriaceae species infecting grapevines. Phytopathologia Mediterranea, 50: 5-45.

32. Uysal, A. \& Kurt, S. 2019. In vitro sensitivity of anthracnose disease agent, Colletotrichum gloeosporioides (Penz.) Penz. \& Sacc., to some fungicides on lemon. Plant Protection Bulletin, 59(1): 53-62.

33. Yan, JY., Xie, Y., Zhang, W., Wang, Y., Liu, JK., Hyde, KD., Seem, RC., Zhang, GZ.,Wang, ZY, Yao, SW., Bai, XJ., Dissanayake, AJ., Peng, YL. \& Li, XH. 2013. Species of Botryosphaeriaceae involved in grapevine dieback in China. Fungal Diversity, 61: 221-236. 